\title{
Effect of Mulches and Varieties on Nutrient Content and Quality of Green Gram (Vigna radiata)
}

\author{
Rajpal Bochliya*, M. L. Reager and C. Swetha \\ Department of Agronomy, Swami Keshwanand Rajasthan Agricultural University, \\ Bikaner-334006, Rajasthan, India \\ *Corresponding author
}

\section{A B S T R A C T}

Keywords

Mulching,

Varieties,

Nutrient Content, Quality

\section{Article Info}

Accepted:

12 May 2020

Available Online:

10 June 2020

\begin{abstract}
A field experiment was counducted at Agronomy Farm, College of Agriculture, Swami Keshwanand Rajasthan Agricultural University, Bikaner during kharif season 2017. "Effect of Different Mulches on Green Gram (Vigna radiata L.) Varieties in North Western Rajasthan"

The experiment comprising of four mulching (no mulch, dust mulch, live mulch and mustard straw mulch) and four varieties (HUM 16, IPM-02-03, SML 668 and GM 4) comprising a total of 16 treatment combinations in RBD (Factorial Randomised Blok Design ) with three replications. Results showed that different mulches (dust mulch, live mulch and mustard straw mulch) significantly affected nitrogen and phosphorus uptake over no mulch. Live mulch, mustard straw mulch and dust mulching remain statistically at par with each other and live mulch recorded significantly higher nitrogen uptake by seed $(46.6 \mathrm{~kg} / \mathrm{ha})$.However mustard straw mulch remain statistically at par with live mulch and dust mulch recorded significantly higher nitrogen content in straw $(57.1 \mathrm{~kg} / \mathrm{ha})$ and total nitrogen uptake by crop $(103.7 \mathrm{~kg} / \mathrm{ha})$, phosphorus content in seed $(5.0 \mathrm{~kg} / \mathrm{ha})$ and total phosphorus uptake $(10.4 \mathrm{~kg} / \mathrm{ha})$ by crop. Nitrogen and phosphorus uptake in green gram crop were significantly affected by varieties of green gram. Variety SML 668 recorded significantly higher amount of total nitrogen uptake (105.4 kg/ha). However variety SML 668 remain statistically at par with variety HUM 16 and IPM 02-03 recorded higher phosphorus content in seed $(5.1 \mathrm{~kg} / \mathrm{ha})$ and total phosphorus uptake by crop $(10.5 \mathrm{~kg} / \mathrm{ha})$ as compared to GM 4 .
\end{abstract}

\section{Introduction}

Green gram (Vigna radiata $\mathrm{L}$. Wilczek) is an important pulse crop in India and popularly known as moongbean. It belongs to the family leguminoceae sub-family papilionaceae. It is a native of India and Central Asia, (Vavilov, 1926). Moongbean have excellent source of high quality protein and minerals, it contains $24.5 \%$ protein, $59.9 \%$ carbohydrate and 75 $\mathrm{mg}$ calcium, $8.5 \mathrm{mg}$ iron and $49 \mathrm{mg} \mathrm{R}$ - carotene per $100 \mathrm{~g}$ of split dual (Bhowaland and Bhowmik, 2014). Moongbean is consumed as whole grains, sprouted seed used for preparation dhal.

Green gram extensively cultivated in India it occupies $3.4 \mathrm{~m}$ ha area with a production of 1.4 million tonnes with the average yield 475 $\mathrm{kg} \mathrm{ha}^{-1}$ (Anonymous, 2014-15). Rajasthan is first position with $26 \%$ share of total green gram production in India, which produces 
1.05 million tonnes of green gram from 2.12 $\mathrm{m}$ ha area with an average yield $495 \mathrm{~kg}$ ha ${ }^{1}$ (Directorate of Agriculture, Rajasthan, Jaipur 2016-17).

\section{Materials and Methods}

\section{Experimental site, climate characteristics and soil}

A field experiment entitled "Effect of Different Mulches on Green Gram (Vigna radiata L.) Varieties in North Western Rajasthan" was carried out during kharif season of 2017. The experiment was conducted at the Instructional Farm, College of Agriculture, Swami Keshwan and Rajasthan Agricultural University, Bikaner during kharif 2017. College of Agriculture is situated at $28.01^{\circ} \mathrm{N}$ latitude and $73.22^{\circ} \mathrm{E}$ longitude at an altitude of $234.7 \mathrm{~m}$ above mean sea level. Soil of the experimental site was loamy sand in texture with alkaline reaction $(\mathrm{pH} 8.5)$ and organic carbon is very low $(0.08 \%)$.

The climate of this zone is typically arid characterized by aridity of the atmosphere and slight salinity in the rhizosphere with extremes of temperatures both in summers and winters. The average annual rainfall of the tract is about $260 \mathrm{~mm}$ which is mostly received during the rainy season from July to September.

There is wide range of temperatures both in rainy and winter seasons $\left(4.1\right.$ to $\left.41.1^{\circ} \mathrm{C}\right)$. This region is prone to high wind velocity and soil erosion due to dust storms in summer. The relative humidity of the locality fluctuates in between 20 to 85.9 per cent during 2017. The bright sunshine in kharif season of 2017 was recorded to be 5.7 to 9.9 . The total rainfall during crop growing season was $124.1 \mathrm{~mm}$. The soil textural class of experimental site was Loamy Sand, low carbon, nitrogen content and slight saline $\mathrm{pH} 8.2$.

\section{Treatments and experimental design}

The total number of treatments were applied sixteen with four types of mulching (Control, Dust mulching, Live mulching $5 \mathrm{t} \mathrm{ha}^{-1}$ and Mustard straw mulching $5 \mathrm{t} \mathrm{ha}^{-1}$ ) and four varieties of green gram (HUM 16, IPM02-03, SML 668 and GM 4) respectively. The treatments were applied in randomized block design with three replications. Crop sown at a distance of $30 \mathrm{~cm}$ and $10 \mathrm{~cm}$ plant to plant distance within row and net plot size $1.8 \mathrm{~m} \mathrm{X}$ $3.0 \mathrm{~m}$.

\section{Crop establishment and management}

Seeds of green gram were treated with carbendazim (2 $\mathrm{g} \mathrm{kg}^{-1}$ seed) as prophylactic measures against seed borne disease. The crop varieties as per treatment, HUM 16, IPM-0203, SML 668 and GM 4 were sown by "kera" method in rows spaced at $30 \mathrm{~cm}$ apart with 5 $\mathrm{cm}$ soil depth on 19 July 2017 using seed rate of $20 \mathrm{~kg} \mathrm{ha}^{-1}$.Pre-sowing irrigation (palewa) of $60 \mathrm{~mm}$ was applied before crop sowing to ensure uniform and adequate moisture at before sowing 18 july 2017 time and later all irrigation applied on the base of crop requirement. The calculated amount of chemical fertilizers $\left(20 \mathrm{~kg} \mathrm{~N}\right.$ and $32 \mathrm{~kg} \mathrm{P}_{2} \mathrm{O}_{5}$ $\mathrm{ha}^{-1}$ ) were applied through urea and $\mathrm{Di}$ ammonium phosphate. Full dose of nitrogen $\left(20 \mathrm{~kg} \mathrm{ha}^{-1}\right)$ and phosphorus (32 $\left.\mathrm{kg} \mathrm{ha}^{-1}\right)$ were applied in field at the time of sowing. One spray of imidaclorprid 17.8\% SL@ $250 \mathrm{ml}$ $\mathrm{ha}^{-1}$ in 1000 litre water was done to protect the crop from sucking pest as per schedule on 11.09.2018.

\section{Nutrient content and uptake}

\section{Nutrient content}

The representative samples of seed and straw drawn at the time of threshing and winnowing were ground to pass through 40 mesh sieve 
and analyzed for nitrogen and phosphorus concentration.

\section{Nitrogen}

Nitrogen was estimated by digesting the samples with sulphuric acid using hydrogen peroxide to remove black colour. Estimation of nitrogen was done by Kjeldahl's method. Nitrogen content was calculated and expressed in percentage.

Methods of determination of $\mathbf{N}$ and $\mathbf{P}$ content in crop (seed and straw)

\begin{tabular}{|l|l|l|}
\hline S.No. & Nutrient & \multicolumn{1}{|c|}{ Methods followed } \\
\hline 1. & Nitrogen & $\begin{array}{l}\text { Kjeldahl's method } \\
\text { (Hambelton and Noel, } \\
\text { 1975) }\end{array}$ \\
\hline 2. & Phosphorus & $\begin{array}{l}\text { Vanadomolybdo } \\
\text { phosphoric acid, } \\
\text { yellow colour method } \\
\text { (Jackson, 1973) }\end{array}$ \\
\hline
\end{tabular}

\section{Phosphorus}

Phosphorus concentration in seed and straw was determined by Vanadomolybdo phosphoric acid, yellow colour method. Digestion of samples was done by tri-acid mixture and the intensity of colour was measured by Spectrophotometer (Jackson, 1973).

\section{Nutrient uptake}

The uptake of nitrogen and phosphorus in seed as well as straw after harvest was estimated by using the following relationship:

\begin{tabular}{|l|l|l|l|l|l}
\hline $\begin{array}{l}\text { Nutrient } \\
\text { uptake }= \\
\left(\mathrm{kg} \mathrm{ha}^{-1}\right)\end{array}$ & $\begin{array}{l}\text { Nutrient content } \\
\text { in seed }(\%)\end{array}$ & $\begin{array}{l}\text { Seed yield } \\
\left(\mathrm{kg} \mathrm{ha}^{-1}\right)\end{array}$ & $\begin{array}{c}\text { Nutrient } \\
\text { content in straw } \\
(\%)\end{array}$ & $\begin{array}{l}\text { Straw } \\
\times \text { yield } \\
\left(\mathrm{kg} \mathrm{ha}^{-1}\right)\end{array}$ \\
\hline
\end{tabular}

\section{Protein content in seed}

The per cent protein content in seed of each plot was worked out by multiplying the nitrogen content in seeds with conversion factor 6.25 for green gram (A.O.A.C, 1960)..

\section{Results and Discussion}

Effect of different mulching on nitrogen, phosphorus and protein content of green gram

The data present in table 1 that nitrogen content in both (seed and straw), phosphorus content in both (seed and straw) and protein content in seed were not significantly affected by different mulching in green gram.

\section{Effect of varieties on nitrogen, phosphorus} and protein content of green gram

The data present in table 1 that nitrogen content in both (seed and straw), phosphorus content in both (seed and straw) and protein content in seed were not affected by varieties of green gram.

Effect of different mulching on nitrogen and phosphorus uptake of green gram

The data presented in table 2 releved that the nitrogen and phosphorus uptake were affected by different mulching in green gram. Live mulch remain statistically at par with mustard straw mulch and dust mulch recorded significantly higher nitrogen content in seed (46.6 kg/ha). However mustard straw mulch remain statistically at par with live mulch and dust mulch recorded significantly higher nitrogen content in straw $(57.1 \mathrm{~kg} / \mathrm{ha})$ and total nitrogen uptake by crop $(103.7 \mathrm{~kg} / \mathrm{ha})$, phosphorus content in seed $(5.0 \mathrm{~kg} / \mathrm{ha})$ and total phosphorus uptake $(10.4 \mathrm{~kg} / \mathrm{ha})$ by crop. Nitrogen and phosphorus uptake were significantly influenced by different mulching 
in green gram. Live much, remained statistically at par with mustard straw mulch recorded significantly higher nitrogen and phosphorus uptake by seed, straw and plant, over control (Table 2). The increase in total nitrogen uptake with dust mulch, live mulch and mustard straw mulch was 13.31, 16.58 and 19.89 pre cent, respectively over control. However uptake increase in total phosphorus with dust mulch, live mulch and mustard straw mulch was $8.39,12.11$ and 14.71 per cent, respectively over control.

Reduced photosynthesis and decreased translocation of assimilates to the grain during drought result in lower grain weight and produce more empty grains (Liu et al., 2008). The improvement in the nutrient uptake under mulching might be due to maintenance of higher soil moisture in root zone which resulted in increased growth, LAI and DMA, photosynthesis etc. resulting in better nutrient uptake (Monneveux et al., 2006).

Effect of varieties on nitrogen and phosphorus uptake of green gram

Nitrogen and phosphorus uptake in green gram crop were significantly affected by varieties of green gram. Variety SML 668 recorded significantly higher amount of total nitrogen uptake (105.4 kg/ha).

However variety SML 668 remain statistically at par with variety HUM 16 and IPM 02-03 recorded higher phosphorus content in seed $(5.1 \mathrm{~kg} / \mathrm{ha})$ and total phosphorus uptake by crop $(10.5 \mathrm{~kg} / \mathrm{ha})$ as compared to GM 4 .

Table.1 Effect of mulching and varieties on Nitrogen, phosphorus and protein content of green gram

\begin{tabular}{|c|c|c|c|c|c|}
\hline \multirow[t]{2}{*}{ Treatments } & \multicolumn{2}{|c|}{$\begin{array}{c}\text { Nitrogen } \\
\text { content }(\%)\end{array}$} & \multicolumn{2}{|c|}{$\begin{array}{l}\text { Phosphorus } \\
\text { content }(\%)\end{array}$} & \multirow{2}{*}{$\begin{array}{c}\text { Protein } \\
\text { content in } \\
\text { seed }(\%)\end{array}$} \\
\hline & Seed & Straw & Seed & Straw & \\
\hline \multicolumn{6}{|l|}{ Mulching } \\
\hline Control & 3.77 & 2.16 & 0.40 & 0.22 & 23.55 \\
\hline Dust mulching & 3.69 & 2.32 & 0.40 & 0.22 & 23.05 \\
\hline Live mulching & 3.66 & 2.18 & 0.38 & 0.21 & 22.90 \\
\hline Mustard straw mulching & 3.67 & 2.32 & 0.40 & 0.22 & 22.91 \\
\hline SEm \pm & 0.09 & 0.09 & 0.01 & 0.01 & 0.54 \\
\hline $\mathrm{CD}(\mathrm{P}=\mathbf{0 . 0 5})$ & NS & NS & NS & NS & NS \\
\hline \multicolumn{6}{|l|}{ Varieties } \\
\hline HUM 16 & 3.77 & 2.24 & 0.40 & 0.22 & 23.57 \\
\hline IPM 02-03 & 3.60 & 2.18 & 0.39 & 0.22 & 22.51 \\
\hline SML 668 & 3.58 & 2.33 & 0.39 & 0.22 & 22.38 \\
\hline GM 4 & 3.84 & 2.22 & 0.40 & 0.21 & 23.97 \\
\hline SEm \pm & 0.09 & 0.09 & 0.01 & 0.01 & 0.54 \\
\hline $\mathrm{CD}(\mathrm{P}=\mathbf{0 . 0 5})$ & NS & NS & NS & NS & NS \\
\hline
\end{tabular}

NS=Non-significant 
Table.2 Effect of mulching and varieties on nitrogen and phosphorus uptake of green gram

\begin{tabular}{|l|c|c|c|c|c|c|}
\hline \multirow{2}{*}{ Treatments } & \multicolumn{3}{|c|}{$\begin{array}{c}\text { Nitrogen uptake } \\
\left(\mathbf{k g ~ h a}^{-1}\right)\end{array}$} & \multicolumn{3}{c|}{$\begin{array}{c}\text { Phosphorus uptake } \\
\text { (kg ha-1) }^{-1}\end{array}$} \\
\cline { 2 - 7 } Mulching & seed & Straw & Total & seed & Straw & Total \\
\hline Control & & & & & & \\
\hline Dust mulching & 41.0 & 45.5 & 86.5 & 4.3 & 4.6 & 9.1 \\
\hline Live mulching & 44.0 & 54.0 & 98.0 & 4.7 & 5.0 & 9.8 \\
\hline Mustard straw mulching & 46.6 & 54.2 & 100.9 & 4.8 & 5.3 & 10.1 \\
\hline SEm \pm & 46.5 & 57.1 & 103.7 & 5.0 & 5.3 & 10.4 \\
\hline CD (P=0.05) & 1.37 & 2.51 & 2.66 & 0.15 & 0.21 & 0.29 \\
\hline Varieties & 3.96 & 7.24 & 7.69 & 0.44 & NS & 0.83 \\
\hline HUM 16 & & & & & & \\
\hline IPM 02-03 & 44.6 & 52.9 & 97.6 & 4.7 & 5.2 & 10.0 \\
\hline SML 668 & 42.7 & 50.2 & 92.9 & 4.6 & 5.0 & 9.6 \\
\hline GM 4 & 47.2 & 58.1 & 105.4 & 5.1 & 5.4 & 10.5 \\
\hline SEm \pm & 43.6 & 49.6 & 93.3 & 4.4 & 4.7 & 9.1 \\
\hline CD (P=0.05) & 1.37 & 2.51 & 2.66 & 0.15 & 0.21 & 0.29 \\
\hline
\end{tabular}

$\mathrm{NS}=$ Non-significant

The varieties under study differed significantly in their total nitrogen and phosphorus uptake. The highest amount of $\mathrm{N}$ and $\mathrm{P}$ was taken up by variety SML 668 followed by HUM 1 (Table 2). Nutrient uptake is depending on concentration of cellular level and dry-matter production. Hence, in spite of marginal variation in nutrient concentration, higher nutrient uptake could be due to increased biological yield. The high dry matter in the variety SML 668 may be traced to the significant difference in nutrient uptake and that reason may be attributed to their genetic variability, varietal difference and environmental adaptability (Samant, 2014).

\section{References}

Anonymous (2014-15) Government of India, Department of Agriculture \&
Cooperation.

Directorate of Agriculture, Rajasthan, Jaipur 2016-17.

Liu, K., Ye, Y., Tang, C., Wang, Z. and Yang, J. (2008). Responses of ethylene and ACC in rice grains to soil moisture and their relations to grain filling. Frontiers of Agriculture in China 2(2):172-180.

Monneveux, P., Sanchez, C., Beck, D. and Edmeades, G.O. (2006). Drought tolerance improvement in tropical maize source populations: evidence of progress. Crop Science 46:180-191.

Samant, T.K. (2014). Evaluation of growth and yield parameters of green gram (Vigna radiata L.). Agriculture Update, 9(3): 427-430.

Vavilov, N.I. (1926). Studies on origins of cultivated plants. Bulletin of Applied Botany and Plant Breeding, 16: Pp1245. 
How to cite this article:

Rajpal Bochliya, M. L. Reager and Swetha, C. 2020. Effect of Mulches and Varieties on Nutrient Content and Quality of Green Gram (Vigna radiata). Int.J.Curr.Microbiol.App.Sci. 9(06): 75-80. doi: https://doi.org/10.20546/ijcmas.2020.906.009 